\title{
Sarcoma of the Thigh: Radical Excision with Arterial Reconstruction Using the Contralateral Saphenous Vein
}

\author{
Piero Covarelli, MD, $\mathrm{PhD}^{1}$, Carlo Boselli, MD, $\mathrm{PhD}^{1}$, Gloria Burini, $\mathrm{MD}^{1}$, Basso Parente, $\mathrm{MD}^{2}$, Diletta Loschi, $\mathrm{MD}^{2}$, \\ Massimo Lenti, $\mathrm{MD}, \mathrm{PhD}^{2}$, and Antonio Rulli, $\mathrm{MD}^{1}$ \\ ${ }^{1}$ Department of Surgery, University of Perugia, Perugia, Italy; ${ }^{2}$ Section of Vascular Surgery, Perugia General Hospital, \\ Perugia, Italy
}

Soft tissue sarcomas are a heterogeneous group of malignant mesenchymal neoplasms that frequently affect large muscle of the thigh. ${ }^{1}$ A conservative limb-salvage surgery involving en bloc resection of the whole tumor with surrounding healthy tissue ${ }^{2}$ can sometimes be considered instead of amputation to achieve good local disease control while preserving a satisfying function of the affected limb. ${ }^{1-3}$

The massive vascular encasement, once regarded as a contraindication to limb-salvage surgery, can sometimes be encompassed thanks to vascular axis reconstruction. ${ }^{3}$ Although no doubt exists about the need for reconstruction of the femoral artery with quite good reported results, the venous replacement is a controversial issue with unclear patency rates, yet this replacement is mandatory when superficial and deep femoral veins are removed together with the saphenous vein. ${ }^{2}$ The femoral artery is commonly replaced with an autologus reversed saphenous vein graft because of its resistance to infections and its excellent patency rates ${ }^{2-4}$ compared with artificial grafts. ${ }^{4,5}$

We present a case of thigh sarcoma involving the femoral vascular axis with complete clogging of the femoral vein due to massive deep thrombosis. The video illustrates the features of the case and highlights the steps of a wide compartment resection with arterial reconstruction by autologus reversed saphenous vein graft.

\section{REFERENCES}

1. Bains R, Magdum A, Bhat W, Roy A, Platt A, Stanley P. Soft tissue sarcoma: a review of presentation, management and outcomes in 110 patients. Surgeon. 2014. doi:10.1016/j.surge. 2014.06.002

2. Muramatsu K, Ihara K, Miyoshi T, Yoshida K, Taguchi T. Clinical outcome of limb-salvage surgery after wide resection of sarcoma and femoral vessel reconstruction. Ann Vasc Surg. 2011;25:1070 7. doi:10.1016/j.avsg.2011.05.009 (Epub 10 August 2011).

3. Chao AH, Mayerson JL, Chandawarkar R, Scharschmidt TJ. Surgical management of soft tissue sarcomas: extremity sarcomas. J Surg Oncol. 2014. doi:10.1002/jso.23810.

4. Ramamurthy R, Soundrarajan JC, Mettupalayam V, Shanmugham $\mathrm{S}$, Arumugam B, Periasamy S. Limb conservation in extremity soft tissue sarcomas with vascular involvement. Indian J Orthop. 2009;43:403-7. doi:10.4103/0019-5413.54969.

5. Klinkert P, Post PN, Breslau PJ, van Bockel JH. Saphenous vein versus PTFE for above-knee femoropopliteal bypass: a review of the literature. Eur J Vasc Endovasc Surg. 2004;27:357-62.
Electronic supplementary material The online version of this article (doi:10.1245/s10434-015-4844-1) contains supplementary material, which is available to authorized users.

(C) Society of Surgical Oncology 2015

First Received: 19 February 2015; Published Online: 8 September 2015

P. Covarelli, MD, $\mathrm{PhD}$

e-mail: piero.covarelli@unipg.it 